\title{
MODEL BASED ON BALANCED SCORECARD APPLIED TO THE STRATEGIC PLAN OF A PERUVIAN PUBLIC ENTITY
}

Francisco Fernando Juárez Regalado EUPG Escuela Universitaria de Posgrado -UNFV, Universidad Tecnológica del Perú-UTP, (Perú). E-mail: ffjuarezr@hotmail.com ORCID: https://orcid.org/0000-0002-3942-7832

Doris Esenarro

EUPG Escuela Universitaria de Posgrado - Universidad Nacional Federico Villarreal, (Perú). E-mail: desenarro@unfv.edu.pe ORCID: https://orcid.org/0000-0002-7186-9614

Mónica Díaz Reátegui

EUPG Escuela Universitaria de Posgrado - Universidad Nacional Federico Villarreal

Universidad Norbert Wiener, (Perú).

E-mail: monicdre@yahoo.com ORCID: https://orcid.org/0000-0003-4506-7383

Maurice Frayssinet Delgado

EUPG Escuela Universitaria de Posgrado - Universidad Nacional Federico Villarreal, (Perú).

E-mail: mfrayssinet@gmail.com ORCID: https://orcid.org/0000-0001-6223-2577

Recepción: 15/09/2021 Aceptación: 09/11/2021 Publicación: 24/11/2021

\section{Citación sugerida:}

Juárez, F. F., Esenarro, D., Díaz, M., y Frayssinet, M. (2021). Model based on balanced scorecard applied to the strategic plan of a peruvian public entity. 3C Empresa. Investigación y pensamiento crítico, 10(4), 127-147. https://doi. org/10.17993/3cemp.2021.100448.127-147 


\section{ABSTRACT}

The objective of this research is to propose a design of a model based on a Balanced Scorecard (BSC) applied to the strategic plan of a Peruvian public entity. There is a deficiency of compliance with the objectives of the strategic plan, which results in the low acceptance of public institutions by citizens. The methodology used for this design proposal was based on the BSC management tool. To test the model, a prototype of a solution based on BSG was built for the institutional strategic plan; in the interface, the following results were obtained; the year 2019, the average of the programmed goals of the indicators was 59 , the standard of the execution of the plans was 58, this means an execution percentage of $97 \%$ for 2019. Therefore, it is proposed to reach $100 \%$ by 2020 with the implementation of the proposal.

\section{KEYWORDS}

Balanced Scorecard, Strategic map, Strategic plan, Public entity. 


\section{INTRODUCTION}

The government effectiveness index captures perceptions of the quality of public services, the quality of the civil service and the degree of its independence from political pressures, the quality of policy formulation and implementation, and the credibility of the government's commitment to such policies (The Global Economy, 2021).

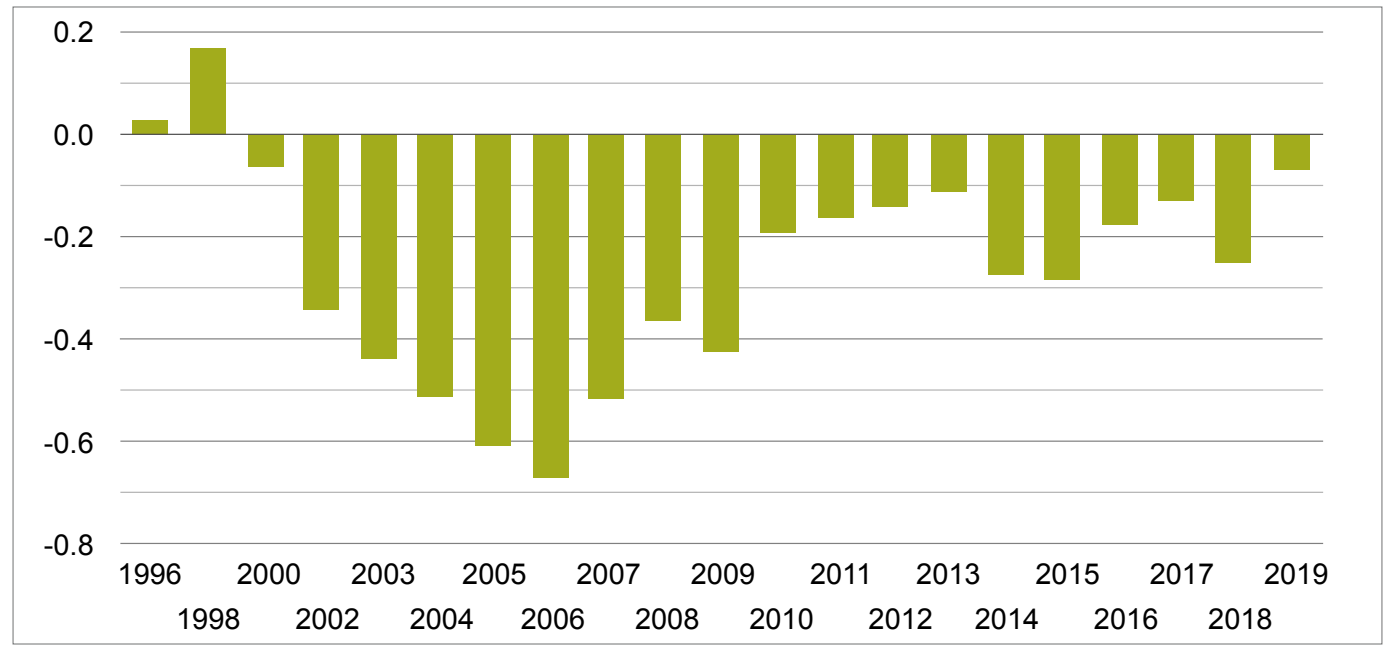

Figure 1. Peru - Government Effectiveness Index 1996-2019.

Source: (The Global Economy, 2021).

Figure 1 shows that Peru's government effectiveness index has been negative in the last two decades. This research work proposes a tool for monitoring the institutional strategic plan based on BSC to reverse these results.

The change in management itself, by following the BSC, implicitly implies an intense activity of internal process improvement and would be subject to operational indicators to measure its evolution. The binomial, customer and stakeholder satisfaction and financial survival require a great effort and a permanent philosophy of optimization (Foncubierta-Rodríguez, Galiana-Tonda, \& Galiana, 2020); globalization has caused that having a vision, mission, objectives, or goals is not enough for the efficient 
fulfillment of the functions. Instead, it requires tools and techniques that make this activity a process capable of complying with strategic management that serves as a source of information for future decision making, particularly the BSC (Moreira \& Murillo, 2020), it is recommended that before the implementation of the model, a review and, if applicable, an adaptation of the map and its strategic objectives, as well as the valuations and weightings of the indicators, since these may also vary according to the needs and priorities of each organization (Murillo, 2020), since its appearance and during the period 1992-2010, the BSC has undergone constant evolution, It emerged as a comprehensive evaluation tool based on economic value, and its continuous development has originated an aligned and global measurement model that allows guiding the organization towards the creation of value, thus responding to the demands of its stakeholders (Pérez, Guillén, \& Bañón-Gomis, 2017).

For the first time since May 2018, Peru has a formal declaration of the General Governance Policy - PGG to 2021. Every public entity must take care of the consistency of its policies and plans with the PGG and the SINAPLAN framework within the firm intention of progressively institutionalizing State policies and best practices at the service of the population in the territory (Centro Nacional de Planeamiento Estratégico (CEPLAN), 2019).

\section{LITERATURE REVIEW}

\section{$\underline{\text { Balanced Scorecard (BSC) }}$}

The BSC ensures alignment between finance, market, technology, and innovation. At the same time, it is indispensable as a communication strategy, management control device, and corporate strategy (Abad, 2019), within the multiple tools that help in decision making in an organization is the BSC, which allows translating the organization's strategy into concrete objectives that can be measured, which can be both financial and non-financial (Castillo, Rodríguez, \& Osma, 2017). 


\section{$\underline{\text { Strategic Plan }}$}

It is common for strategies to be contained in a strategic plan, a tool that is a process comprising the study of the current and future environment of the internal situation, the establishment of goals for a horizon more significant than one year, and the choice of decisions that represent investments, to sustainably satisfy the reason why a company exists or was created (Villajuana, 2013), the strategic plan is a document used to communicate the company's objectives and actions necessary to achieve them (Turban, Volonino, \& Wood, 2015).

\section{$\underline{\text { Strategic Map }}$}

An essential element for the elaboration of the BSC is the elaboration of a strategic map, which constitutes a graphic presentation of the organizational perspectives with the strategic objectives in a cause-effect manner (Ramos et al., 2020), the new framework, which we call strategic map, is a logical and complete structure to describe a strategy, it provides the basis for designing a BSC (Kaplan \& Norton, 2016).

\section{METHODOLOGY}

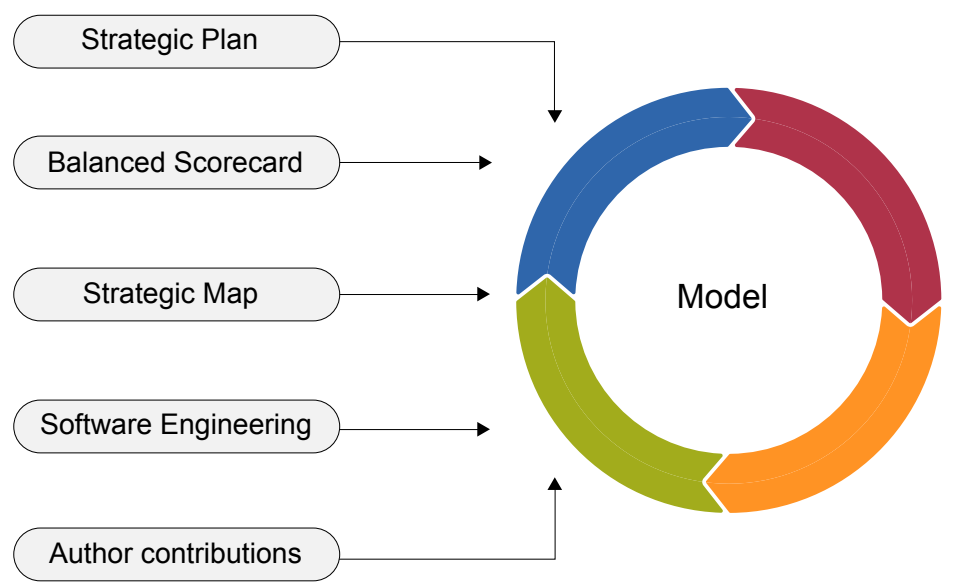

Figure 2. Model based on BSC.

Source: own elaboration. 
Figure 2 shows the methodology proposed in this research, which consists of designing a model based on the BSG management tool and basic software engineering principles. To test it, a prototype of a BSC-based solution for the institutional strategic plan of a Peruvian public entity was built. This implementation includes the following activities.

\subsection{IDENTIFICATION OF THE ELEMENTS OF THE STRATEGIC PLAN}

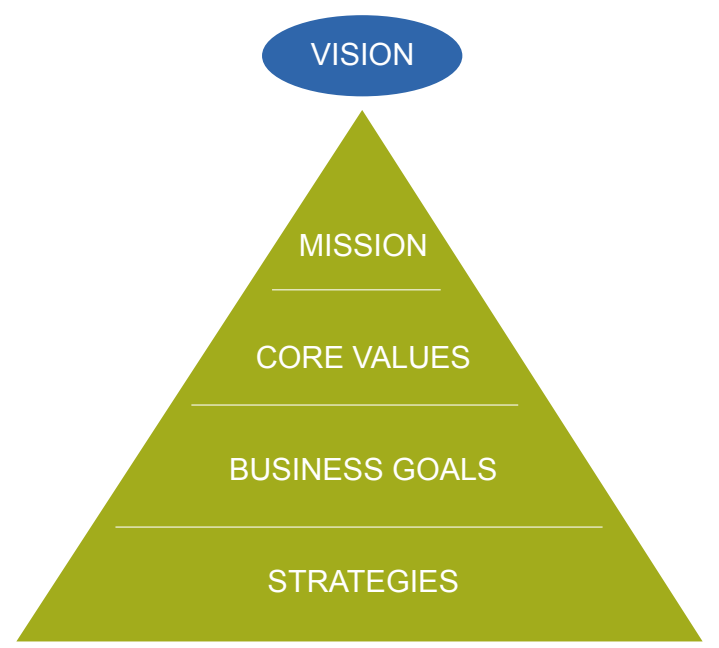

Figure 3. Elements of the strategic plan.

Source: own elaboration.

Figure 3 shows the main elements of the strategic plan; at the top of the pyramid are the general features such as the mission and vision of the organization, while at the base of the pyramid are the more specific elements such as values, objectives, and strategies. These elements of the strategic plan can be extracted from the organization's strategic plan (Alfaro et al., 2020).

\subsection{DEFINITION OF THE BSC PERSPECTIVES}

The perspectives that will group the strategic objectives or indicators proposed in the strategic plan are defined. 


\subsection{PREPARATION OF THE STRATEGY MAP}

The strategy map is drawn up considering the cause-effect relationships identified between the strategic objectives or indicators. Microsoft Visio or similar software can be used.

\subsection{DATABASE IMPLEMENTATION}

\begin{tabular}{|c|c|c|}
\hline \multirow{2}{*}{ TA_PERS_PECT } & TA_MAES PLAN & \multirow[b]{2}{*}{ TA_VALO } \\
\hline & COD_PLAN: CHAR(3) NOT NULL & \\
\hline NRO_ORDE: NUMBER(1) NOT NULL & $\begin{array}{l}\text { YEA_INIC: NUMBER(4) NOT NUL } \\
\text { YEA_FINA: NUMBER(4) NOT NU } \\
\text { MIS:VARCHAR2(300) NULL } \\
\text { VIS:VARCHAR2(300) NULL } \\
\text { USU_CREA:CHAR(18) NOT NUL } \\
\text { USU_MODI: CHAR(18) NULL } \\
\text { FEC_CREA:DATE NOT NULL. } \\
\text { FEC_MODI: DATE NULL } \\
\text { EST_REGI:CHAR(1) NOT NULL }\end{array}$ & $\begin{array}{l}\text { COD_PLAN:CHAR(3) NOT NULL (FK) } \\
\text { COD_VALO:CHAR(2) NOT NULL }\end{array}$ \\
\hline TA_INDI & \multirow{2}{*}{ TA_PRIN_CIPI $\stackrel{\$}{\stackrel{\$}{*}}$} & \multirow[b]{2}{*}{ TA_OBJE_TIVO } \\
\hline COD_PLAN:CHAR(3) NOT NULL (FK) & & \\
\hline $\begin{array}{l}\text { NRO_ORDE: NUMBER(1) NOT NULL (F) } \\
\text { COD_INDI:CHAR(2) NOT NULL. }\end{array}$ & $\begin{array}{l}\text { COD_PLAN: CHAR(3) NOT NULL (FK) } \\
\text { COD_PRIN: CHAR(2) NOT NULL }\end{array}$ & $\begin{array}{l}\text { COD_PLAN: CHAR(3) NOT NULL (FK) } \\
\text { COD_OBJE:CHAR(2) NOT NULL }\end{array}$ \\
\hline $\begin{array}{l}\text { DES_GRAL:VARCHAR2(100) NOT NUL } \\
\text { COD_UNID_MEDI: CHAR(2) NULL (FK) } \\
\text { BAS_YEAR: NUMBER(4) NULL } \\
\text { BAS_VALO:NUMBER(10,2) NULL } \\
\text { USU_CREA:CHAR(18) NOT NULL } \\
\text { USU_MODI: CHAR(18) NULL }\end{array}$ & $\begin{array}{l}\text { DES_GRAL: VARCHAR2(100) NOT NU } \\
\text { USU_CREA:CHAR(18) NOT NULL } \\
\text { USU_MODI: CHAR(18) NULL } \\
\text { FEC_CREA:DATE NOT NULL } \\
\text { FEC_MODI:DATE NULL } \\
\text { EST_REGI:CHAR(1) NOT NULL }\end{array}$ & $\begin{array}{l}\text { DES_GRAL: VARCHAR2(100) NOT NL } \\
\text { USU_CREA: CHAR(18) NOT NULL } \\
\text { USU_MODI:CHAR(18) NULL } \\
\text { FEC_CREA:DATE NOT NULL } \\
\text { FEC_MODI: DATE NULL } \\
\text { EST_REGI:CHAR(1) NOT NULL }\end{array}$ \\
\hline $\begin{array}{l}\text { FEC_CREA: DATE NOT NULL } \\
\text { FEC_MODI: DATE NULL } \\
\text { EST_REGI:VARCHAR2(20) NOT NULL }\end{array}$ & 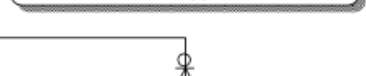 & \\
\hline$\psi$ & TA_INDI_YEAR & \\
\hline 오 & \begin{tabular}{|l|} 
COD_PLAN: CHAR(3) NOT NULL (FK) \\
NRO_ORDE: NUMBER(1) NOT NULL (FF \\
COD_INDI:CHAR(2) NOT NULL (FK) \\
YEA:NUMBER(4) NOT NULL. \\
\end{tabular} & TA_ACCI \\
\hline CO_UNID_MEDI & $\begin{array}{l}\text { FLG_VISL:CHAR(1) NOT NULL } \\
\text { PRO_GRAM:NUMBER(10,2) NOT NULL }\end{array}$ & $\begin{array}{l}\text { COD_PLAN: CHAR(3) NOT NULL (FK) } \\
\text { COD_OBJE:CHAR(2) NOT NULL (FK) }\end{array}$ \\
\hline COD_UNID_MEDI:CHAR(2) NOT NUI & EJE_CUSI: NUMBER $(10,2)$ NULL & CO_ACCl:CHAR(2) NOT NULL \\
\hline $\begin{array}{l}\text { DES_GRAL: VARCHAR2(20) NOT NU } \\
\text { USU_CREA: CHAR(18) NOT NULL } \\
\text { USU_MODI:CHAR(18) NULL } \\
\text { FEC_CREA:DATE NOT NULL } \\
\text { FEC_MODI: DATE NULL. } \\
\text { EST_REGI: CHAR(1) NOT NULL }\end{array}$ & $\begin{array}{l}\text { EJE_CUSI_PORC: NUMBER(5,2) NULL } \\
\text { MIN-NUMBER(10,2) NULL } \\
\text { MAX: NUMBER(10,2) NULL } \\
\text { DES_TINO: NUMBER(10,2) NULL } \\
\text { USU_CREA:CHAR(18) NOT NULL } \\
\text { USU_MODI:CHAR(18) NULL } \\
\text { FEC_CREA:DATE NOT NULL } \\
\text { FEC_MODI: DATE NULL } \\
\text { EST_REGI:CHAR(1) NOT NULL }\end{array}$ & $\begin{array}{l}\text { DES_GRAL: VARCHAR2(100) NOT NL } \\
\text { USU_CREA:CHAR(18) NOT NULL } \\
\text { USU_MODI:CHAR(18) NULL } \\
\text { FEC_CREA:DATE NOT NULL } \\
\text { FEC_MODI: DATE NULL } \\
\text { EST_REGI:CHAR(1) NOT NULL }\end{array}$ \\
\hline
\end{tabular}

Figure 4. Data model of the BSC-based solution.

Source: own elaboration.

Figure 4 shows the data model of the proposed solution elaborated with CA Erwin software; this model must be implemented in a relational database. 


\subsection{ELABORATION OF THE USER INTERFACE}

To display all information obtained from the previous activities, use Microsoft Power BI software or similar.

\begin{tabular}{|c|c|c|}
\hline GREEN & YELLOW & RED \\
\hline$>=90 \%$ & $<90 \%$ & \\
& $>=50 \%$ & $<50 \%$ \\
\hline
\end{tabular}

Figure 5. Color scale.

Source: own elaboration.

Figure 5 shows the proposed color scale for the graphical indicator of the percentage of execution. Green indicates that it is possible to meet the goal, yellow warns us that the plan may not be met, and red indicates that we are far from meeting the goal.

\section{RESULTS}

The prototype of the BSG-based solution was implemented on the institutional strategic plan of the public entity, applying the proposed methodology. The following activities were carried out:

\subsection{IDENTIFICATION OF THE ELEMENTS OF THE STRATEGIC PLAN}

Table 1. Matrix of Strategic Objectives, Indicators, and Targets.

\begin{tabular}{|c|c|c|c|c|c|c|c|}
\hline \multirow{2}{*}{ Strategic Objective } & \multirow{2}{*}{ Indicator } & \multicolumn{2}{|c|}{ Baseline } & \multicolumn{4}{|c|}{ Goals } \\
\hline & & Value & Year & 2019 & 2020 & 2021 & 2022 \\
\hline \multirow{3}{*}{$\begin{array}{l}\text { OEI.01: Increase access } \\
\text { to and reliability of regis- } \\
\text { try services for citizens. }\end{array}$} & $\begin{array}{c}\text { Percentage of people who receive registry } \\
\text { services directly. }\end{array}$ & 36.85 & 2017 & 39 & 40 & 41 & 42 \\
\hline & $\begin{array}{l}\text { Percentage of citizens with the perception of } \\
\text { security concerning the public entity }\end{array}$ & 68 & 2017 & 70 & 71 & 72 & 73 \\
\hline & $\begin{array}{l}\text { Percentage increase in the number of proper- } \\
\text { ties registered with the public entity }\end{array}$ & 3.46 & 2017 & 4 & 4 & 4 & 4 \\
\hline $\begin{array}{l}\text { OEI.02: Modernize insti- } \\
\text { tutional management for } \\
\text { citizen satisfaction. }\end{array}$ & $\begin{array}{l}\text { Percentage of citizens with the satisfactory } \\
\text { perception of a public entity }\end{array}$ & 75.8 & 2016 & 77 & 78 & 79 & 80 \\
\hline
\end{tabular}


OEI.03: Implement disaster risk management in the public entity.
Percentage of disaster risk management actions programmed and executed.
60
80
85
90

Source: (Superintendencia Nacional de los Registros Públicos (SUNARP), 2020).

Table 1 shows the strategic objectives, indicators, and goals established in the institution's strategic plan.

Table 2. Strategic Route.

\begin{tabular}{|c|c|c|c|c|}
\hline Priority & Strategic objective & PGG Vinculation & Priority & Strategic Actions \\
\hline \multirow{4}{*}{1} & \multirow{4}{*}{$\begin{array}{l}\text { OEI.01: Increase } \\
\text { access to and re- } \\
\text { liability of registry } \\
\text { services for citizens. }\end{array}$} & \multirow{4}{*}{$\begin{array}{l}\text { EJE } 3 \\
\text { POL } 3.2\end{array}$} & 1 & $\begin{array}{l}\text { AEI 01.01: accessible, timely, and predictable registry registration } \\
\text { services for citizens }\end{array}$ \\
\hline & & & 2 & $\begin{array}{l}\text { AEI 01.02: accessible, timely, and predictable registry publicity ser- } \\
\text { vices for citizens. }\end{array}$ \\
\hline & & & 3 & $\begin{array}{l}\text { AEI 01.03: effective registry inclusion programs to promote the for- } \\
\text { malization of the country's most remote and informal populations. }\end{array}$ \\
\hline & & & 4 & $\begin{array}{l}\text { AEI 01.04: Improve the physical and technological infrastructure of } \\
\text { the institution. }\end{array}$ \\
\hline \multirow{3}{*}{2} & \multirow{3}{*}{$\begin{array}{l}\text { OEI.02: Modernize } \\
\text { institutional mana- } \\
\text { gement for citizen } \\
\text { satisfaction. }\end{array}$} & \multirow{3}{*}{$\begin{array}{l}\text { EJE } 3 \\
\text { POL } 3.2\end{array}$} & 1 & $\begin{array}{l}\text { AEI 02.01: simple and efficient administrative and operational pro- } \\
\text { cesses to improve institutional management. }\end{array}$ \\
\hline & & & 2 & AEI 02.02: permanent capacity building for the institution's staff. \\
\hline & & & 3 & $\begin{array}{l}\text { AEI 02.03: optimized registry services processes for the benefit of } \\
\text { citizens }\end{array}$ \\
\hline \multirow[b]{2}{*}{3} & \multirow{2}{*}{$\begin{array}{l}\text { OEI.03: Implement } \\
\text { disaster risk mana- } \\
\text { gement in the insti- } \\
\text { tution. }\end{array}$} & \multirow{2}{*}{$\begin{array}{l}\text { EJE } 3 \\
\text { POL } 3.2\end{array}$} & 1 & $\begin{array}{l}\text { AEI 03.01: effective disaster risk prevention and reduction in the enti- } \\
\text { ty AEI 03.02: training for the institution's staff }\end{array}$ \\
\hline & & & 2 & $\begin{array}{l}\text { AEI 03.02: comprehensive training to respond effectively to emergen- } \\
\text { cies and disasters in the entity AEI 03.02: training to respond effecti- } \\
\text { vely to emergencies and disasters in the entity }\end{array}$ \\
\hline
\end{tabular}

Source: (Superintendencia Nacional de los Registros Públicos (SUNARP), 2020).

Table 2 shows the strategic path established in the institution's strategic plan.

\subsection{DEFINITION OF THE BSC PERSPECTIVES}

The indicators established in the strategic plan were grouped into three perspectives:

- Learning and growth.

- Internal processes.

- Citizenship. 


\subsection{ELABORATION OF THE STRATEGIC MAP}

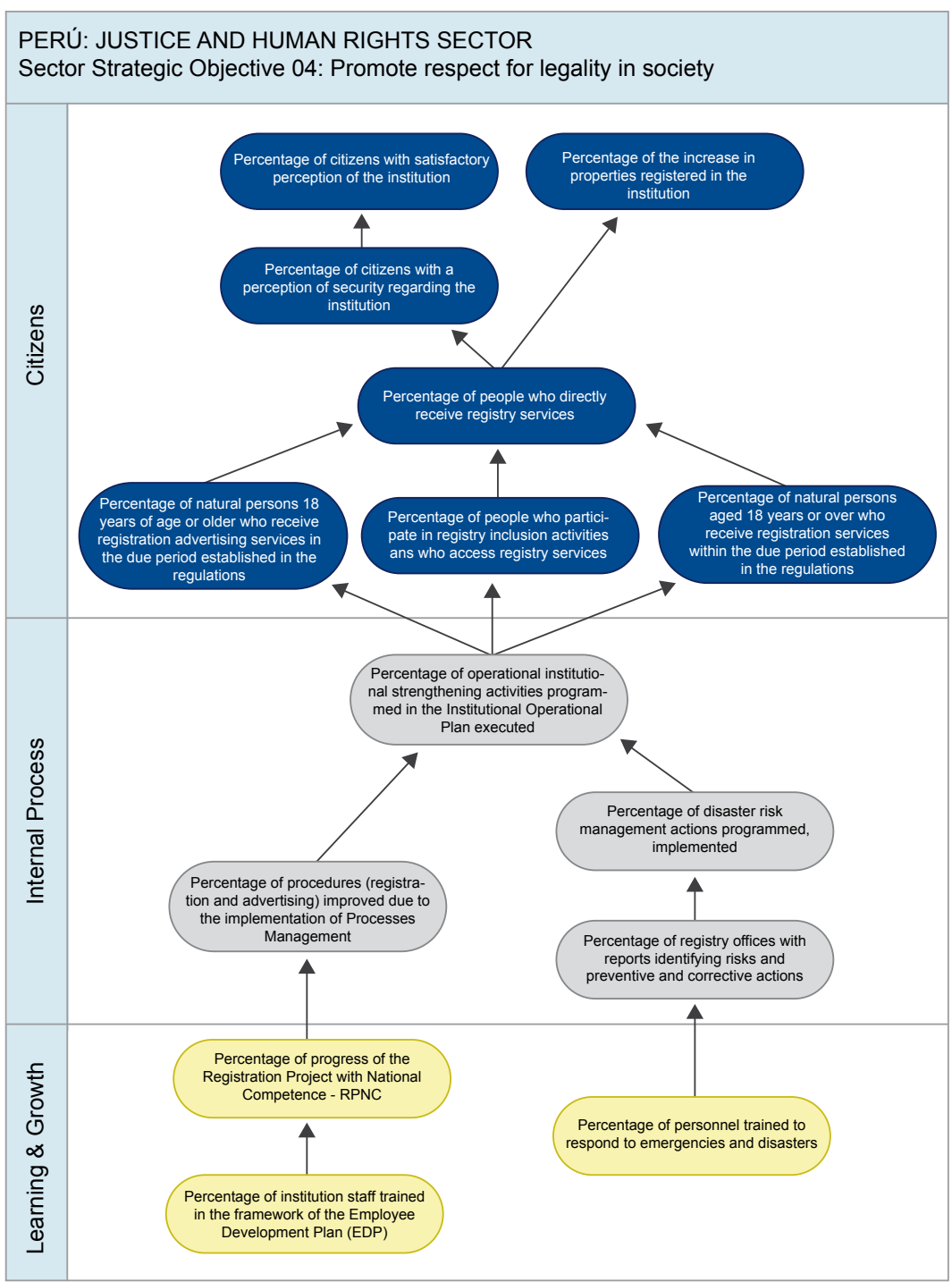

Figure 6. Strategy map of the public entity.

Source: own elaboration. 
Figure 6 shows the institution's strategy map, which represents the indicators and the cause-effect relationships between them. This map allows explaining the results to be achieved and why they will be achieved.

\subsection{DATABASE IMPLEMENTATION}

The proposed data model was implemented in an Oracle database of the Institution; all the necessary information for implementing the BSG-based solution was loaded into this database.

\subsection{DEVELOPMENT OF THE USER INTERFACE}

The solution based on BSC was built using Microsoft Power BI software; in this interface, it is possible to visualize the execution percentage at the following levels:

- At the level of the vision of the institution (the whole BSC).

- At the level of one of the three perspectives.

- At the status of an indicator.

This solution shows the colors proposed in the methodology.

BALANCED SCORECARD
Vision. Perspective, Indicator
Sector Strategic Objective 04: Promote respect for legality in society
1. Learning \& Growth
Percentage of institution staff trained in the framework of the Employee Development Plan (EDP)
Percentage of personnel trained to respond to emergencies and disasters
2. Internal Process
Percentage of disaster risk management actions programmed, implemented
Percentage of operational institutional strengthening activities programmed in the Institutional Operational Plan executed.
Percentage of procedures (registration and advertising) improved due to the implementation of Processes Management
Percentage of registry offices with reports identifying rists and preventive and corrective actions
3. Citizens
Percentage of citizens with a perception of security regarding the institution
Percentage of citizens with satisfactory perception of the institution
Percentage of natural persons 18 years of age or older who receive registration advertising services in the due period established in the regulations
Percentage of natural persons aged 18 years or over who receive registration services within the due period established in the regulations
Percentage of people who directly receive registry services
Percentage of people who participate in registry inclusion activities and who access registry services.
Percentage of the increase in properties registered in the institution


Figure 7. BSC: Average execution percentage for 2019.

Source: own elaboration.

Figure 7 shows that the institution has achieved an average of $97 \%$ execution of the goals programmed for 2019.

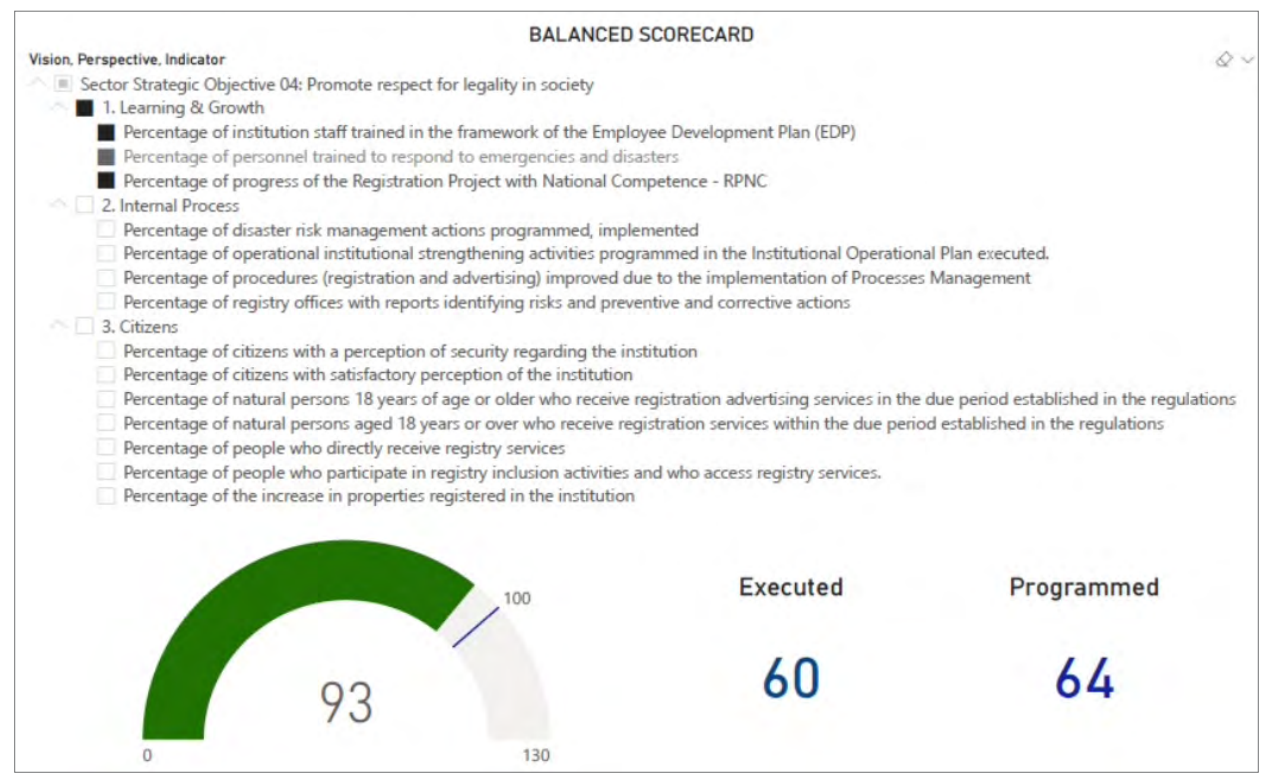

Figure 8. BSC: Average percentage of execution of the learning and growth perspective in 2019.

Source: own elaboration.

Figure 8 shows that the institution has achieved an average of 93\% execution of the programmed goals of the learning and growth perspective for the year 2019. 


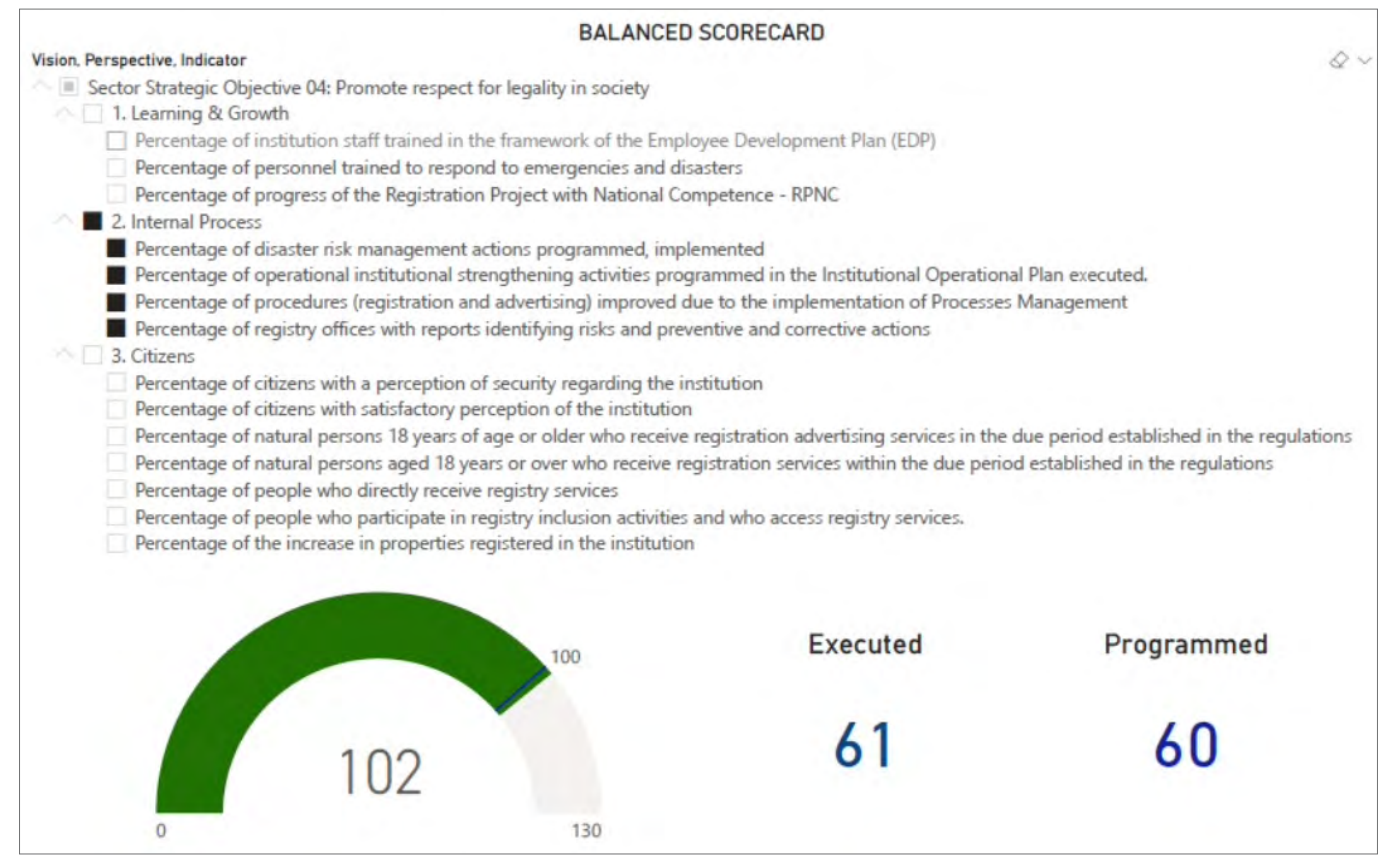

Figure 9. BSC: Average percentage of execution of the internal process perspective in 2019.

Source: Own elaboration.

Figure 9 shows that the institution has achieved an average of $102 \%$ execution of the programmed goals of the internal processes perspective for the year 2019. In this perspective it has exceeded the expectations for that year. 


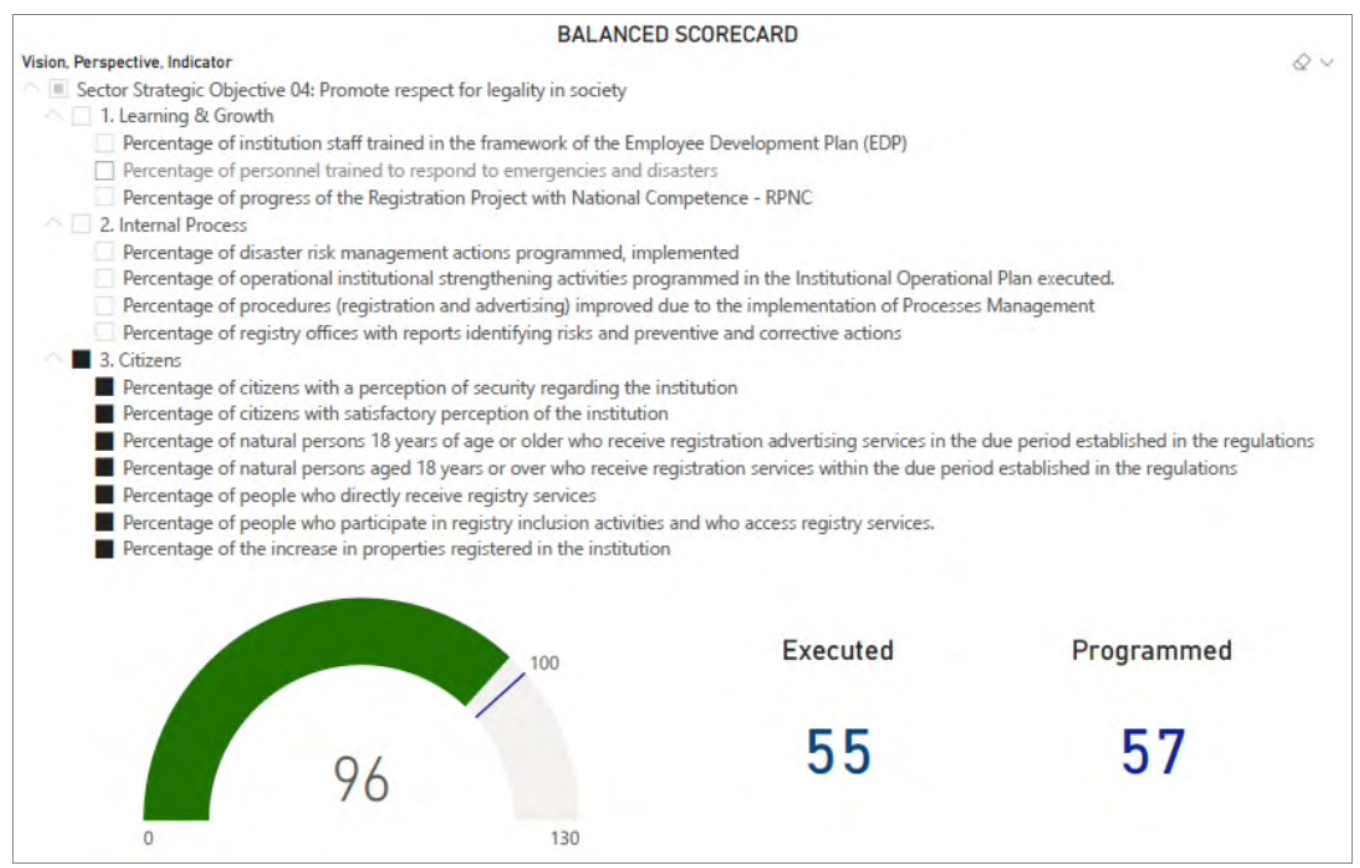

Figure 10. BSC: Average percentage of the citizens' perspective in 2019.

Source: own elaboration.

Figure 10 shows that the institution has achieved an average of $96 \%$ execution of the programmed goals of the citizens' perspective for the year 2019. 


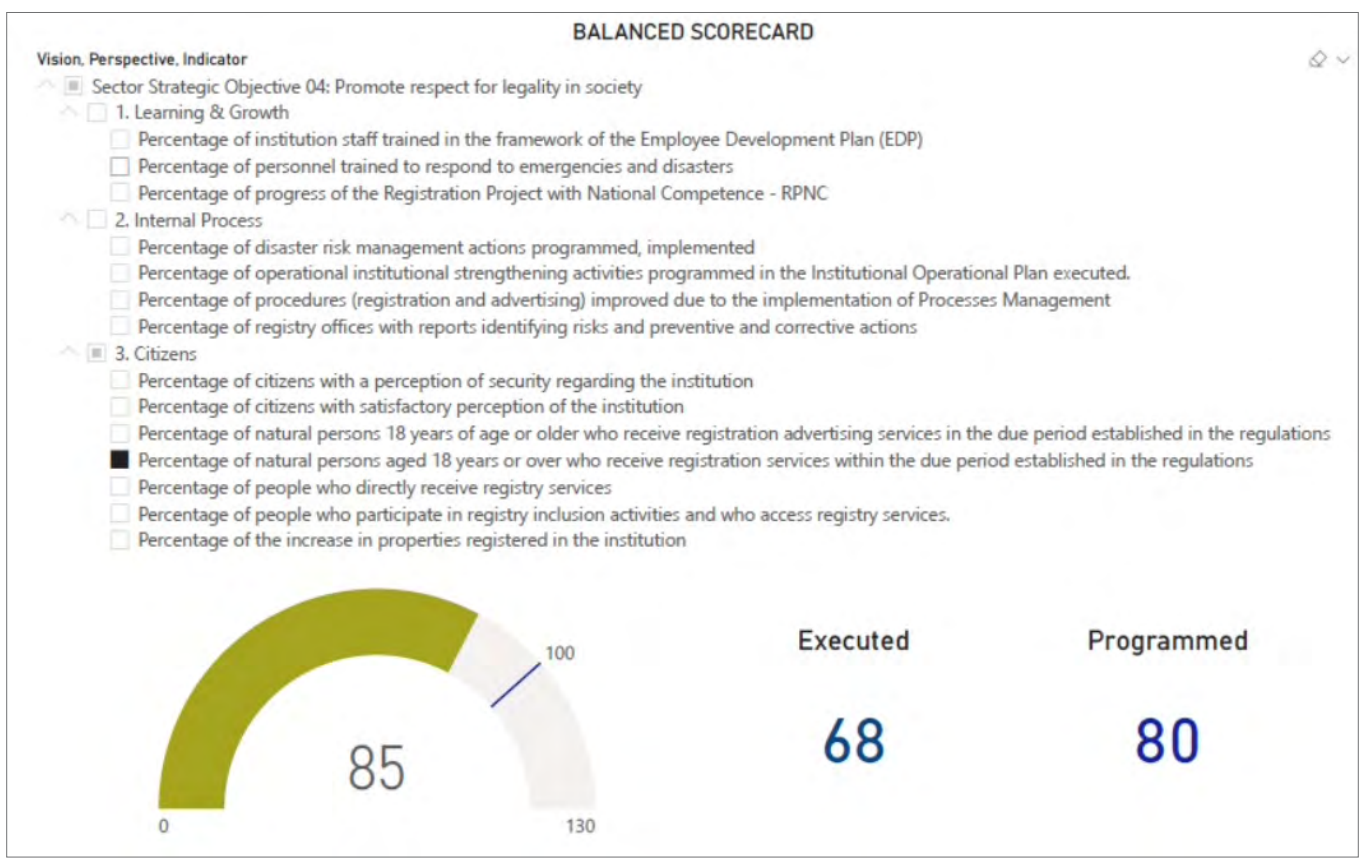

Figure 11. CSB: Percentage of natural persons aged 18 years and older who receive registry registration services within the due date established in the regulations in 2019.

Source: own elaboration.

Figure 11 shows that the institution has reached 85\% execution of the programmed goal of the percentage of natural persons aged 18 years and older who receive registry registration services in the due time established in the regulations for the year 2019. This is the only result shown in yellow. 


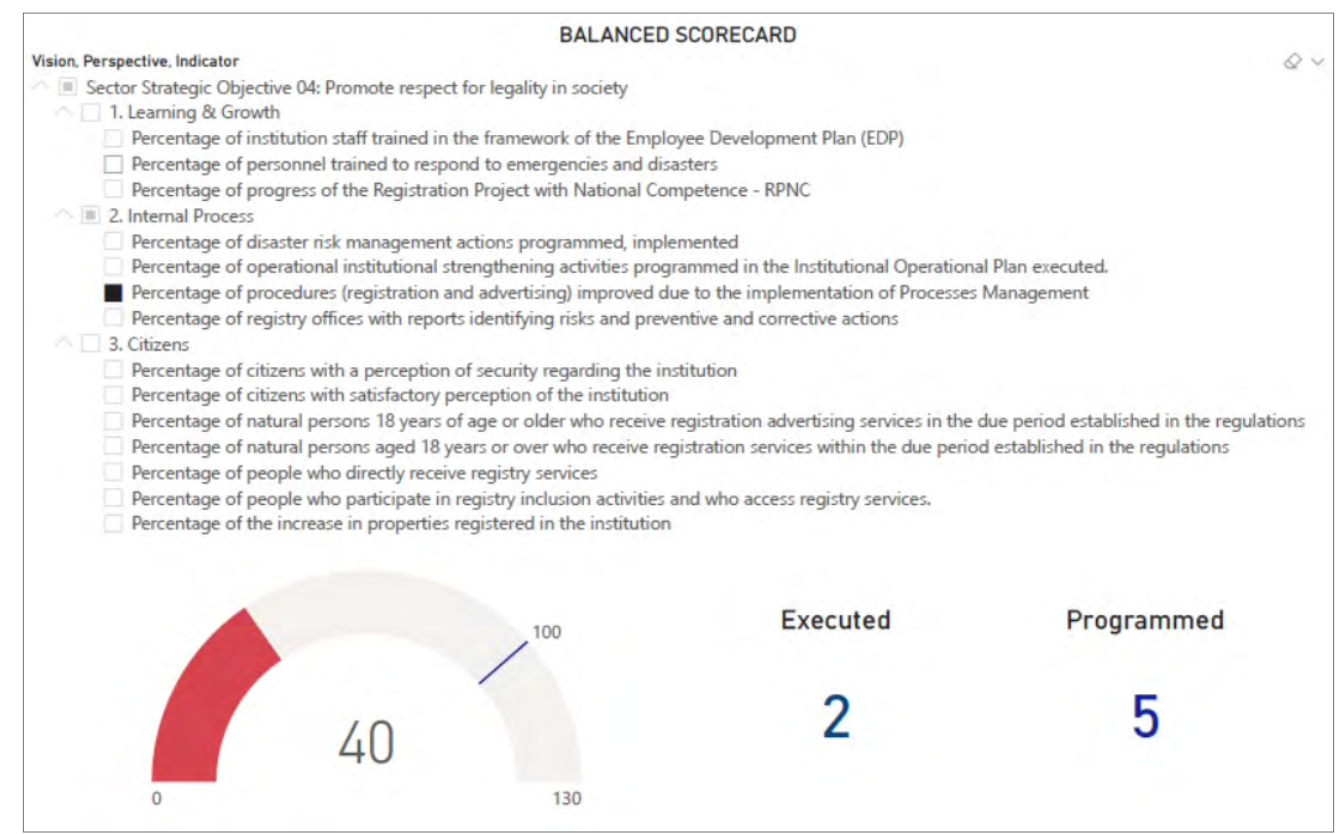

Figure 12. BSC: Percentage of procedures (registration and publicity) improved as part of the implementation of process management in 2019.

Source: own elaboration.

Figure 12 shows that the institution has reached $40 \%$ execution of the programmed goal of the percentage of procedures improved in the framework of implementing the management by processes for the year 2019. This is one of the two results shown in red. 


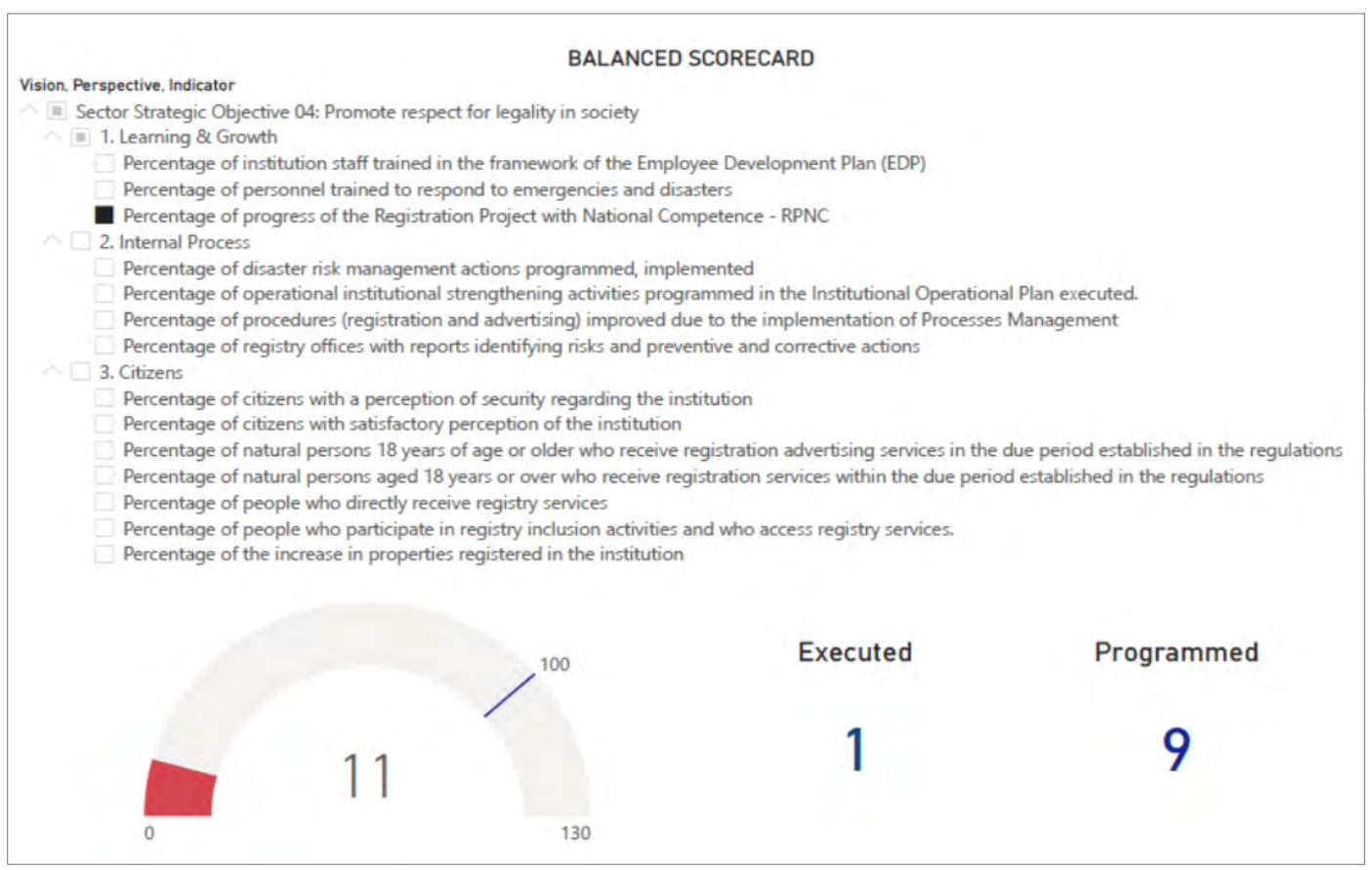

Figure 13. BSC: Percentage of the progress of the Registration Project with National Competence - IRCN in 2019.

Source: own elaboration.

Figure 13 shows that the institution has reached $11 \%$ of the execution of the programmed goal of the percentage of progress of the Registration Registration Project with National Competence - IRGN for the year 2019. This is one of the two results shown in red.

\section{CONCLUSIONS}

The prototype of the BSC-based solution was implemented on the institutional strategic plan of the public entity, applying the proposed methodology. 
The achievement of the objectives corresponding to the learning and growth and internal processes perspectives has a significant impact on the service that the institution provides to the citizen; this is reflected in the strategic map of the public entity.

At the level of the whole year 2019, according to the last report of the public entity, the institution has achieved an average of $97 \%$ of execution of the goals programmed for that year. The BSC shows this result in green.

At the level of the perspectives defined in the BSC, the percentage of execution of the goals programmed for 2019 was as follows: the learning and growth perspective reached an average of $93 \%$ execution. The internal processes perspective reached an average of 102\% execution; this perspective exceeded the expectations for that year. The citizenship perspective achieved an average of $96 \%$ execution. The three views are shown in the BSC in green (Ubalde et al., 2020).

At the indicator level, 85\% of the programmed target for the percentage of individuals 18 years of age and older who receive registry registration services due to time established in the regulations was reached. This is the only result shown in yellow in 2019. It is also noted that $40 \%$ execution of the programmed goal of the percentage of procedures improved in the framework of the implementation of process management was achieved; the BSC shows this result in red color. It is also observed that $11 \%$ of the programmed goal of the percentage of progress of the Registry Registration Project with National Competence - IRCN was achieved, the BSC shows this result also in red color (Alfaro et al., 2020).

The proposed model provides the relevant information of the strategic plan. Therefore it should be taken into account when strategic decisions are to be made in an organization, allowing the fulfillment of the objectives set out in the plan.

The model proposed in this research work can be taken as a basis for a similar implementation in any public or private organization. 


\section{REFERENCES}

Abad, P. (2019). El Cuadro de Mando Integral Aplicado a la Planificación Estratégica de la Banca Privada.//The Balanced Scorecard Applied to the Strategic Planning of Private Banking. CIENCIA UNEMI, 12(29), 20-35. http://ojs.unemi.edu.ec/index.php/cienciaunemi/article/ view/748

Alfaro, O., Esenarro, D., Rodriguez, G., \& Alfaro, M. R. (2020a). The Unified Enterprise Architecture (AEU) as a strategic tool organizational modeling for the funtional competitiveness of universities. 3C Empresa. Investigación y pensamiento crítico, edición especial (Tourism and University: Backbone of Peruvian Economy), 63-79. https://doi.org/10.17993/3cemp.2021.specialissue1.63-79

Alfaro, O., Esenarro, D., Rodriguez, G., \& Rene, M. (2020b). The balanced scorecard (BSG) as a support to the CMMI-DEV constellation SCAMPI for the recognition of the maturity of the software process. 3C Tecnología. Glosas De innovación Aplicadas a La Pyme, edición especial (35-2), 33-49. https://ojs.3ciencias.com/index.php/3c-tecnologia/article/view/1088

Castillo, L.Y., Rodríguez, D.P., \& Osma, J. (2017). Modelo de Simulación para evaluar las decisiones estratégicas de un comité local de AIESEC basados en el Balanced Scorecard. RISTI: Revista Ibérica de Sistemas e Tecnologias de Informação, 25, 82-97. https://dialnet.unirioja.es/servlet/ articulo? codigo $=6673822$

Gentro Nacional de Planeamiento Estratégico (GEPLAN). (2019). Guía para el Planeamiento Institucional. Ceplan. 
Foncubierta-Rodríguez, M., Galiana-Tonda, F., \& Galiana, M. del M. (2020). Chambers of commerce: A new management. the balanced scorecard approach for spanish chambers. [Cámaras de comercio: Una nueva gestión. El enfoque del cuadro de mando integral en las cámaras españolas] CIRIEC-Espana Revista De Economia Publica, Social y Cooperativa, (99), 273-308. https://doi.org/10.7203/CIRIEG-E.99.14602

Kaplan, R., \& Norton, D. (2016). Cómo utilizar el Cuadro de Mando Integral (2nd ed.). Gestión 2000.

Lamé, G., Jouini, O., \& Stal-Le Cardinal, J. (2019) Combining Soft Systems Methodology, ethnographic observation, and discrete-event simulation: A case study in cancer care. Fournal of the Operational Research Society, 71(10). https://doi.org/10.1080/01605682.2019.1610339

Moreira-Choez, J., \& Murillo-Mora, M. (2020). Cuadro de mando integral para gestión estratégica en instituciones de educación superior. Diagnóstico Universidad Técnica de Manabí. Polo del Conocimiento, 5(3), 255-282. http://dx.doi.org/10.23857/pc.v5i3.1335

Murillo, L.M. (2020). Cuadro de mando integral para la gestión del impacto social en organizaciones de empleo inclusivo. CIRIEC-España, Revista de Economía Pública, Social y Cooperativa, 98, 153-188. https://doi.org/107203/CIRIEG-E.98.13368

Pérez, L., Guillén, M., \& Bañón-Gomis, A. J. (2017). Influence of contingency factors in the development of the BSC and its association with better performance. the case of spanish companies. [Influencia de los factores de contingencia en el desarrollo del cuadro de mando integral y su asociación con un rendimiento mejor. El caso de las empresas españolas]. Revista De Contabilidad-Spanish Accounting Reviere, 20(1), 82-94. https:/ / doi.org/10.1016/j.rcsar.2016.07.002 


\section{Ramos, I. N., Madrigal, A. D., Gonzalez, O., Figueredo, R. W., Rodriguez-Gallo, Y., Barroceta,}

G. R., \& Gomez, Y. (2020). Balanced scorecard as a tool for sport managers. an approach from cuban baseball. [El cuadro de mando integral como herramienta para gestores deportivos: Un acercamiento desde el béisbol cubano]. Sport TK, 9(2), 7-16. https://doi.org/10.6018/ sportk.431061

Superintendencia Nacional de los Registros Públicos (SUNARP). (2020). Plan Estratégico Institucional PEI 2019 - 2023. Ampliación del Horizonte.

The Global Economy. (2021). Eficacia gubernamental-Clasificaciones. https:/ / es.theglobaleconomy.com/ rankings/wb_government_effectiveness/

Turban, E., Volonino, L., \& Wood, G. (2015). Information Technology for Management - Digital Strategies for Insight, Action, and Sustainable Performance (10th ed.). Wiley.

Ubalde, R., Rodriguez, C., Petrlik, I., Esenarro, D., Lezama, P., \& Sotomayor, J. (2020). Quality model for Peruvian micro-enterprises of a software product Factory. Test Engineering and Management, 83, 13434. 